\title{
BASIC PROPERTIES OF SENTANG WOOD (Melia excelsa Jack) AND ITS SUITABILITY AS ORIENTED STRAND BOARD MATERIALS
}

\author{
Sifat Dasar Kayu Sentang dan Pemanfaatannya sebagai Bahan Baku Oriented Strand Board \\ Apri Heri Iswanto, Fauzi Febrianto, dan Imam Wahyudi
}

\begin{abstract}
Tujuan penelitian ini adalah untuk melihat kesesuaian kayu sentang sebagai bahan baku berdasarkan tinjauan sifat dasarnya dalam hal ini anatomi, fisis, dan kimia. Metode yang digunakan dalam penentuan struktur kayu yaitu teknik maserasi dan mikrotom, sifat fisik berdasarkan standar BS-373 (1957), dan sifat kimia menggunakan standar TAPPI. Hasil penelitian menunjukkan bahwa (1) struktur kayu: kayu sentang cocok dipergunakan sebagai bahan baku OSB karena memiliki dinding sel tipis sampai sedang, pori relatif banyak. Ini merupakan dua faktor yang berperan penting dalam hal perekatan dan proses pengempaan; (2) sifat fisik: kayu sentang memiliki BJ sedang, nilai T/R untuk kering udara dan oven masing-masing 1,25 and 1,17; serta (3) sifat kimia: kayu sentang memiliki kandungan ekstraktif sedang, kandungan selulosa tinggi dan lignin dan kadar abu sedang.
\end{abstract}

Kata kunci: kayu sentang, struktur kayu, fisis, kimia

\section{INTRODUCTION}

The trend of wood supply for wood industries from natural forest in Indonesia in the last decade showed sharply decreased. On the other hand, due to the lack of wood supply as raw material for wood industry in Indonesia, the cost of wood reached to about $60-65 \%$ from the product price (BRIK, 2007). It was reported that up to the first quarter 2008, the total area of timber estate developed in Indonesia is around 3.032 million hectares (Ministry of Forestry of Indonesia, 2008). It is predicted that in the near future the supply of wood from timber estate and community forest will play dominant role for substituting the wood supply from natural forest in Indonesia.

Sentang wood (Melia excelsa Jack) is one of the promoting fast growing tree species that can be introduced in timber estate and community forest. $M$. excelsa wood has bulk density around 0.42-0.52 with medium strength and belong to non durable wood (Ching, 2003; Iswanto, 2008). The extractive content of $M$. excelsa after dissolved in cold water, hot water, $1 \%$ sodium hydroxide $(\mathrm{NaOH} 1 \%)$ and alcohol-benzene were in the range of 4.25 $5.07 \%, 7.39-7.83 \%, 9.29-11.19 \%$, and $2.09-2.64 \%$, respectively (Iswanto, 2008). M. excelsa wood can be used for light construction, furniture, panel and veneer. Hence, M. excelsa wood is also promoting to be used as a raw material for OSB product.
Basic properties (anatomy, physical and chemical) of sentang wood must be knew to determined optimal pretreatment for resulting OSB that fulfill requirement.

\section{MATERIALS AND METHODS}

\section{Materials}

Sentang wood, alcohol, glyserine, aquadest, ethanol, benzene, natrium hydroxyde $(\mathrm{NaOH})$, acetat acid $\left(\mathrm{CH}_{3} \mathrm{COOH}\right)$, natrium sulfit $\left(\mathrm{NaSO}_{3}\right)$, natrium hypoclorite $(\mathrm{NaClO} 3)$, and sulfat acid $\left(\mathrm{H}_{2} \mathrm{SO}_{4}\right)$

\section{Methods}

1. Wood structure observation (i.e fibre, cell wall, pore, and rays): microtome and maseration technique.

2. Physical properties of wood

Evaluation method of physical properties (i.e specivic gravity, moisture content, and shrinkage) refers to British Standard (BS-373).

3. Chemical properties of wood

Evaluation method of chemical properties (i.e extractive, cellulose, hemicellulose, lignin, and ash content) refers to TAPPI standard (Technical Assosiation of the Pulp and Paper Industry). 
Table 1. The average value of fibre dimension, pore and rays

\begin{tabular}{lcc}
\hline \multicolumn{1}{c}{ Parameter } & Value & Information \\
\hline Fibre length $(\mu \mathrm{m})$ & 1323.93 & Moderate \\
Fibre diameter $(\mu \mathrm{m})$ & 48.18 & - \\
Vessel diameter $(\mu \mathrm{m})$ & 41.57 & - \\
Cell wall thickness $(\mu \mathrm{m})$ & 3.30 & - \\
Pore diameter $(\mu \mathrm{m})$ & 110.00 & Rather small \\
Amount of pore $/ \mathrm{mm}^{2}$ & 10.92 & Quite a lot \\
Rays wide $(\mu \mathrm{m})$ & 64.29 & Rather wide \\
Rays high $(\mathrm{mm})$ & 0.49 & Very short \\
Rays frequency (amount/mm) & 5.80 & Rarely \\
\hline
\end{tabular}

\section{RESULTS AND DISCUSSIONS}

\section{Wood structure of sentang wood}

The average value of wood structure showed that in Table 1. Wood structure had effect on adhesive process especially of adhesive flow or penetration in wood (Ruhendi et al. 2007). Cell wall thickness and vessel diameter determined to specific gravity. Diameter and amount of pore, rays frequency had effect on ability of wood to absorp adhesive.

Wood fibre length in this research included in moderate classes. Sentang wood has thin to moderate fibre diameter and cell wall. Sentang wood used in the research show rather small diameter so its not porous. According to pore diameter, sentang wood had low permeability. Ching (2003) said that sentang wood has low treatability although those wood can preservative bonded. According to Vick (1999), cell rays with radial orientation can give over flow and penetration. The observative by microscopic show that, pore of sentang wood has formation diffuse system with various size. In generally, domination of pore is soliter, but some of pore there is which radial and tangential join. Over penetration also caused starving the join. This wood has rarely paratracheal parenchyme. Rays of sentang wood is rather wide, very shortness and rarely. Rays type is heterocellular multiseriate cell 2-4.

\section{Physical properties of sentang wood}

The average value of physical properties showed that in Table 2. From Table 2, we know that specific grafity of sentang wood was among 0.42-0.52 and it was categorized in medium specific gravity. The excelsior of specific gravity determined that wood has thickness in cell wall and small vessel so that adhesive can not doing better penetration, as the effect that interlock action only occurred in the first or second layer (Ruhendi et al. 2007). According to specific gravity, sentang wood suitable for utilization as composites material, it's related with board compaction ratio to get light in weight and high strength of board. According to Ruhendi et al. 2007, water in wood determined moisture content

Table 2. The average value of physical properties

\begin{tabular}{|c|c|c|c|c|c|}
\hline \multicolumn{2}{|c|}{ Position } & \multirow{2}{*}{ Specivic gravity } & \multirow{2}{*}{$\begin{array}{l}\text { Moisture content } \\
\text { (wet) }(\%)\end{array}$} & \multirow{2}{*}{$\begin{array}{c}\text { Moisture content } \\
\text { (Air drying) (\%) }\end{array}$} & \multirow{2}{*}{$\begin{array}{c}\text { Shrinkage } \\
(\%)\end{array}$} \\
\hline Vertical & Horizontal & & & & \\
\hline \multirow[t]{3}{*}{ Pole } & G & 0.52 & 54.80 & 15.33 & 11.40 \\
\hline & T & 0.48 & 58.72 & 15.58 & 10.62 \\
\hline & $\mathrm{R}$ & 0.49 & 61.03 & 15.67 & 10.89 \\
\hline \multirow[t]{3}{*}{ Medium } & G & 0.47 & 56.48 & 15.12 & 9.45 \\
\hline & T & 0.44 & 75.07 & 15.40 & 10.72 \\
\hline & $\mathrm{R}$ & 0.44 & 80.15 & 15.52 & 11.67 \\
\hline \multirow[t]{3}{*}{ Top } & G & 0.48 & 66.64 & 15.70 & 11.45 \\
\hline & T & 0.43 & 58.10 & 15.21 & 11.37 \\
\hline & $\mathrm{R}$ & 0.42 & 71.37 & 15.51 & 10.06 \\
\hline
\end{tabular}

Remarks: G: Periphery T: medium R: Center 
Table 3. The average value of longitudinal, radial and tangential shrinkage

\begin{tabular}{lcccc}
\hline \multicolumn{1}{c}{ Shrinkage } & Longitudinal (\%) & Radial (\%) & Tangential (\%) & T/R ratio \\
\hline Air drying & 0.46 & 1.79 & 1.97 & 1.25 \\
Oven drying & 1.81 & 4.44 & 4.99 & 1.17 \\
\hline
\end{tabular}

of glue line and will effect to deepness penetration and maturation of adhesive. Moisture content for adhesive bonding depend on adhesive type and process. In generally moisture content for good penetration adhesive is $6-14 \%$.

The average value of $T / R$ ration in air and oven dry condition showed that in Table 3. From the Table 3, sentang wood had T/R ratio on air and oven drying condition are respectivelly 1.25 and 1.17. This is show that sentang wood had good dimension stability. According to Panshin and de Zeeuw (1980), T/R ratio value $\sim 1.00$ can indication that wood was stable. The alteration of dimension caused efect to adhesive bonding performance. Shrinkage and swelling can break of wood and adhesive bonding (Ruhendi et al. 2007).

\section{Chemical properties of sentang wood}

The average value of chemical content showed that in Table 4. From the result in Table 4, based on classification of Indonesian hardwood chemical component in Pari et al. (2006) that sentang wood had medium extractive content (especially for ethanol benzena solution), high cellulose content, medium lignin content, and medium ash content. According to Ruhendi et al. (2007), extractive can give effect on decrease of hygroscopicity, permeability and give increase of wood durability. In wood adhesion, extractive will effect on $\mathrm{pH}$, caused contamination and decrease of penetration. Non polar extractive like terpene and fatic acid (its soluble in ethanol benzena) were one of mean factor that can hinder of adhesive bonding. That materials can soluble in adhesive especially acid adhesive and its can hinder of wetting or penetrating of adhesive. Cellulose and hemicellulose very will influence to physical and mechanical of wood, this part caused hygroscopicity behaviour in cell wall. The hydroxyl group in cellulose and hemicellulose had responsibility on water afinity and potential to form hydrogen bonding, but lignin had fewer free hydroxyl group so its not hygroscopic (Ahmadi, 1990).

\section{CONCLUSIONS}

1. Wood structure; fibre length of sentang wood was classified into moderat classes, sentang wood had quite a lot amount of pore and rather small diameter, rays of rather wide, very short, and rarely amount.

2. Physical properties of wood; according to specific gravity, sentang wood had medium density and good stability. It's had T/R ratio value 1.25 and 1.17 for air and oven drying condition respectively.

3. Chemical properties of wood; sentang wood had medium extractive content, high cellulose content, medium lignin content, and medium ash content.

Table 4. The average value of chemical properties

\begin{tabular}{lcccc}
\hline \multicolumn{1}{c}{ Parameter } & Periphery & Medium & Center & Average \\
\hline Extractive content: & & & & \\
- Cold water (\%) & 4.32 & 4.25 & 5.07 & 4.55 \\
- Hot water (\%) & 7.38 & 7.83 & 7.39 & 7.53 \\
- Ethanol Benzena 1:2 (\%) & 2.13 & 2.09 & 2.64 & 2.29 \\
- NaOH 1\% (\%) & 10.11 & 9.29 & 11.19 & 10.20 \\
Holocellulosa (\%) & 76.77 & 73.13 & 74.60 & 74.83 \\
Celullosa (\%) & 56.66 & 49.30 & 52.72 & 52.89 \\
Hemicellulosa (\%) & 20.11 & 23.83 & 21.88 & 21.94 \\
Lignin (\%) & 23.49 & 25.65 & 23.90 & 24.35 \\
Ash content (\%) & 0.70 & 0.91 & 0.87 & 0.83 \\
\hline
\end{tabular}


4. According to wood structure physical properties and chemical content (especially of extractive content), sentang wood was suitable for structural composites material (especially of OSB).

\section{REFERENCES}

Achmadi, S.S. 1990. Kimia Kayu. Departemen Pendidikan dan Kebudayaan Direktorat Jenderal Pendidikan Tinggi, Pusat antar Universitas IImu Hayat, IPB. Bogor

Badan Revitalisasi Industri Kehutanan, 2007. Hutan rakyat: Peran yang makin nyata. BRIK INFO, 4:1 2.

British Standard. 1957. Methods of Testing Small Clear Specimens of Timbers BS 373, British Standard, Inggris,

Ching, T.S. 2003. Treatability of Sentang Wood (Azadirachta excelsa). [Thesis]. Malaysia.

Iswanto, A.H. 2008. Basic properties of sentang wood (Melia excelsa Jack) and its utilization as

Diterima : 22 April 2009

\section{Apri Heri Iswanto}

Forest Protection Laboratory

Department of Forestry, Faculty of Agricultur

North Sumatera University - Indonesia

e-mail: apriheri@yahoo.com

Fauzi Febrianto, dan Imam Wahyudi

Lab. Sifat Dasar dan Teknologi Kimia Kayu

Department of Forest Products, Faculty of Forestry

Bogor Agriculture University. Fahutan-Kampus IPB

Dramaga, Bogor 16680, Indonesia oriented strand board materials. [Thesis].

Bogor: Posgraduated School, Bogor Agricultural University.

Panshin, A.J. dan C. de Zeeuw. 1980. Text Book of Wood Technology: Structure, Identification, Properties and Uses of The Commercial Woods of The United States and Canada. McGraw-Hill Book Company, Inc. New york

Pari, G., H. Roliadi, D. Setiawan, dan Saepuloh. 2006. Komponen Kimia Sepuluh Jenis Kayu Tanaman Dari Jawa Barat. Jurnal Penelitian Hasil Hutan 24: 89-97.

Ruhendi, S., D.N. Koroh, F.A. Syamani, Nurhaida, Hikmayanti, S. Saad, and T. Sucipto. 2007. Analisis Perekatan Kayu. Fakultas Kehutanan IPB. Bogor

Vick, C.B. 1999. Adhesive Bonding of Wood Material. In: Wood Handbook: Wood as an Engineering Material. Forest Product Technology. USDA Forest Service. Wisconsin. 